\title{
ENVIRONMENTAL AND COST-EFFECTIVENESS COMPARISON OF DUAL FUEL PROPULSION OPTIONS FOR EMISSIONS REDUCTION ONBOARD LNG CARRIERS
}

UDC 629.542:629.5.016

Review paper

\begin{abstract}
Summary
The selection of the suitable propulsion system for LNG carrier highly affects the ship capital and life cycle costs. The current paper compares between the available propulsion systems for LNG carriers from environmental and economic points of view operated with heavy fuel oil (HFO) and marine gas oil (MGO). In addition, the cost-effectiveness for emission reduction due to using dual fuel propulsion options using natural gas fuel (NG) is calculated. As a case study, large conventional LNG carrier class has been investigated. The results show that steam turbine (ST), Ultra-ST, dual fuel diesel engine (DFDE), and combined gas and steam (COGAS) propulsion options can comply with $\mathrm{NO}_{\mathrm{x}}$ and $\mathrm{SO}_{\mathrm{x}}$ emissions regulations set by IMO using dual fuel mode with NG percentages of $87.5 \%, 82 \%, 98.5 \%$ and $94 \%$, respectively. DFDE operated with pilot HFO and NG is the most economic propulsion option. It reduces the dual fuel costs by 1.37 MUS $\$$ /trip compared with HFO cost. The annual cost-effectiveness for the most economic and emission compliance propulsion option is 6.07 $\$ / \mathrm{kg}, 6.39 \$ / \mathrm{kg}$, and $0.55 \$ / \mathrm{kg}$ for reducing $\mathrm{NO}_{\mathrm{x}}, \mathrm{SO}_{\mathrm{x}}$, and $\mathrm{CO}_{2}$ emissions, respectively.
\end{abstract}

Key words: $\quad$ LNG carriers; Propulsion options; Boil-off gas; Environmental and economic analysis; EEDI; Fuel saving cost-effectiveness

\section{Introduction}

The demand on natural gas supply has been increased in the last years to reduce the exhaust gas emissions especially the greenhouse gas [1,2]. Because of these demands, liquefied natural gas (LNG) market is increasing with the increased number of LNG vessels [3-5]. LNG reduces the gas volume by 600 times using deep cooling of $-163{ }^{\circ} \mathrm{C}$ at a pressure slightly higher than the atmospheric pressure $[6,7]$. Boil-off gas (BOG) is one of the main characteristics of the LNG tanks [8]. Therefore, the selection of the LNG carrier propulsion system is constrained by LNG properties and different economic and environmental factors [9]. There is no standard marine power plant for LNG ships [10]. Different propulsion systems are installed onboard varying from turbines to internal combustion engines.

LNG carriers are designed according to the gas code regulations of the international maritime organization (IMO). The gas tanks are built using "cargo containment system". 
They are arranged as spherical (moss), membrane, or prismatic type tanks [11]. BOG occurs in these tanks due to the heat transfer from the surrounding environment which results in evaporation of the liquefied gases. This evaporation rate is increased during cargo transportation [12-14].

On the other hand, the application of natural gas in marine engines depends on its properties. Natural gas is lighter than air, and in the case of leakage it disperses to the atmosphere. Evaporation process of the LNG makes it easy to float away unlike other liquid fuels which remain near the engine and the bilge. The flammability of NG is only possible within a tight mixture with air ranging (5\%: $15 \%$ ). The properties of NG and conventional marine fuel oil are summarized in Table 1 [15-17].

Table 1 Comparison between NG and marine fuel oil properties

\begin{tabular}{lll}
\hline Property & Marine fuel oil & Natural gas \\
\hline Ignition temperature, ${ }^{\circ} \mathrm{C}$ & 250 & 600 \\
Density, $\mathrm{kg} / \mathrm{m}^{3} @ 1 \mathrm{bar}$ & 850 & 0.74 \\
$\mathrm{LCV}, \mathrm{MJ} / \mathrm{kg}$ & 42 & 50 \\
Carbon contents $(\%)$ & 84.7 & 70 \\
Hydrogen contents $(\%)$ & 12 & 20 \\
\hline
\end{tabular}

\section{Propulsion options for LNG carriers}

The type and the classification of LNG propulsion system are highly affected by the generation of the BOG and the emission regulations set by the IMO [12]. Steam turbine (ST) based propulsion system was the first system to be used for LNG carriers since 1960 [18]. It is allowed for burning the used fuel together with the generated BOG during transportation. In 2003, internal combustion engines replaced the ST, due to the improvement in their performance and efficiency. In addition, the dual fuel diesel engine (DFDE) permits the burning of the BOG with the heavy fuel oil [19]. DFDE was started in 4-stroke engine, since 2003. At present, 2-stroke engines can also use NG as a fuel. This can lead to a dramatically change in the LNG propulsion system [14]. The main propulsion systems used in LNG carriers are steam turbine, DFDE, slow speed diesel engine, and gas turbine in combined cycle.

\subsection{Steam turbine propulsion (ST)}

Steam turbine is the first propulsion system used for LNG carriers because of the boiler flexibility to burn the natural BOG from the cargo. This propulsion system normally consists of two boilers each produces steam with a rate of 80-90 ton/hr at $60-70$ bar and $520{ }^{\circ} \mathrm{C}$ [20]. The total power of the plant is 35-45 MW produced through high, intermediate, and low pressure turbines. For speed reversal, the low pressure turbine incorporates a stern turbine on the same rotor shaft. The electric power demand onboard is supplied by two steam turbines generators and one medium-speed diesel generator. The estimated overall thermal efficiency of $30 \mathrm{MW}$ conventional steam power plant powered by Mitsubishi is 35\% [21]. In order to improve the thermal efficiency of the steam power plant, reheating of the high pressure steam turbine is incorporated [14, 22]. This improved cycle is called Ultra Steam Turbine (UST) as shown in Fig. 1a. The modified cycle saves $15 \%$ of the fuel consumption compared with the conventional steam power plant with an overall fuel efficiency of $41 \%$. This can be 
considered as a competitive to the DFDE power plant from fuel consumption point of view [23-25].

\subsection{Dual fuel diesel engine (DFDE)}

Medium speed diesel engines can be considered as an alternative to the conventional steam turbines with low fuel efficiency. They can burn both the liquid and gas fuels in the dual fuel mode. The BOG is used in the gas mode operation with lean air to fuel ratio on the principle of the Otto cycle with pilot diesel fuel injection in the cylinder for ignition. The engine is operated using a completely liquid fuel, marine diesel oil (MDO) or heavy fuel oil (HFO), when the amount of the BOG is insufficient. In this case, the BOG is burned in the gas combustion unit (GCU) with the disadvantage of the energy loss. This loss associated with the losses of the electrical components of the used propulsion system can be ranged from $6 \%$ to $8 \%$, when comparing DFDE with other marine power plants. Fig. 1b shows the DFDE propulsion plant for an LNG carrier. This system uses electric propulsion where the electrical power for both the propulsion and the cargo handling are in altered operating time phase which reduces the net power requirement compared with the mechanical propulsion plant. On the other hand, this propulsion system requires a complex control system especially air to fuel ratio controller $[2,26]$.

\subsection{Slow speed diesel engine (SSDE)}

Slow speed diesel engines are used for LNG carrier propulsion especially for large capacities over $200,000 \mathrm{~m}^{3}$ and the long distance tradeoff ships. It is the most efficient propulsion engine used onboard ships, at the moment. The main advantages of slow speed diesel engine are the high efficiency, low maintenance and operating costs, and the possibility of burning low-quality cheap fuels [27]. This propulsion system uses both the gas combustion unit (GCU) and the reliquefaction plant for the naturally generated BOG as shown in Fig. 1c. The reliquefaction plant converts the generated BOG into a liquid and this reduces any loss in the transported cargo. In case of any breakdown in this system or during any maintenance procedures, the GCU is used to burn the BOG to avoid any damage in the LNG tanks because of the increase in the storage pressure [14]. The auxiliary and electric powers in this propulsion system are provided using 4-stroke diesel generators. In case of twin screw propellers, shaft disconnecting devices are used in each shaft line to immediately disconnect the failed engine from the propulsion shaft line and continue the ship voyage $[28,29]$.

\subsection{Gas Turbines in combined cycle (COGAS)}

The combined cycle is an unusual propulsion system for LNG carriers, because it does not provide a good flexibility especially for auxiliary power generators. Although gas turbines (GT) have many advantages such as good reliability, high power to weight ratio, compact size, and quick response to power demand, ship owners do not prefer using it because of the low fuel efficiency. Most of the applications of the gas turbines in the marine field are used in their combined cycle especially for naval and offshore industry [30-32]. Fig. 1d shows a combined gas and steam turbines (COGAS) propulsion power arrangement for LNG carrier. The gas turbine provides the propulsion torque after using a reduction gear. The exhaust gas boiler is operated using the heat lost in the exhaust gases generated from the gas turbine. It is 
coupled to a generator which provides a mechanical power through the reduction gear to the ship propeller during cruise. At port, both turbines are stopped and three power generators are used for power generation during cargo loading and uploading operations [19, 33].

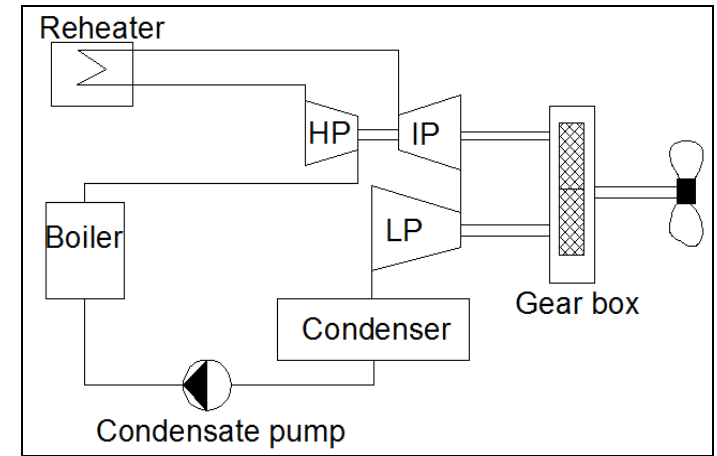

a) Ultra Steam Turbine (UST)

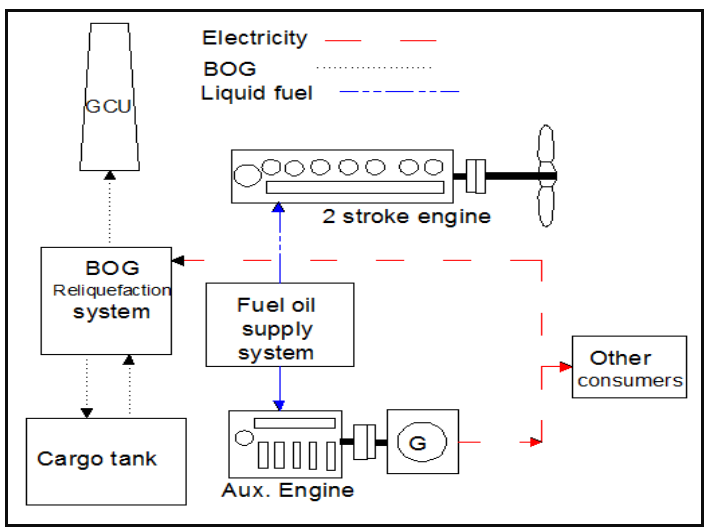

c) 2-stroke diesel engine

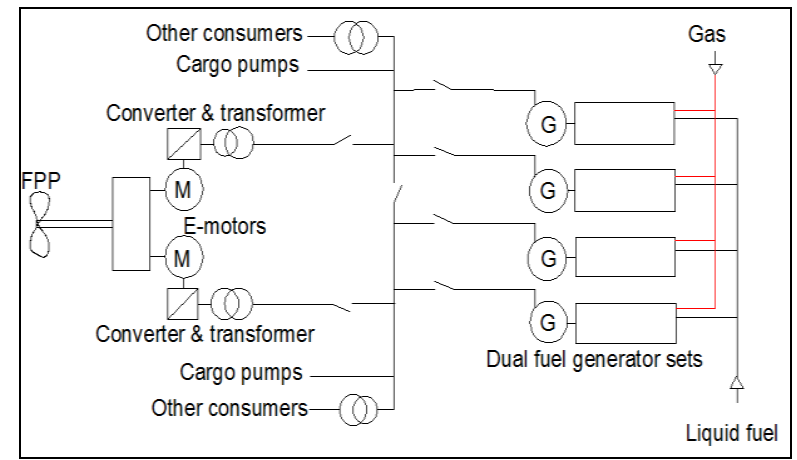

b) Dual fuel four stroke Diesel Engines (DFDE)

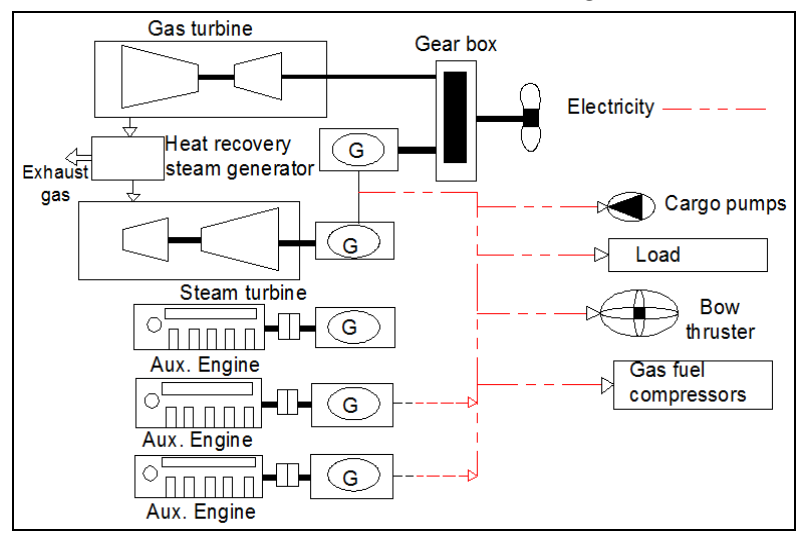

d) Combined gas and steam (COGAS)

Fig. 1 Different LNG propulsion options

The current paper aims to compare between the available propulsion systems for LNG carriers from environmental and economic points of view. The comparison will be performed for the most used marine fuels in LNG carriers' propulsion options. The used fuel for all propulsion options is the heavy fuel oil (HFO) except COGAS operates with marine gas oil (MGO) and DFDE uses both HFO and MGO [2, 14, 22, 34]. In addition, the costeffectiveness for emission reduction due to using the dual fuel propulsion systems is investigated for large conventional LNG carrier.

\section{Large conventional LNG carriers case study}

LNG carriers can be classified into five main classes based on its volumetric capacity of LNG in $\mathrm{m}^{3}$. These classes are small, small conventional, large conventional, Q-flex, and Qmass. They range from small volumes up to $90,000 \mathrm{~m}^{3}$ for the small class and more than $260,000 \mathrm{~m}^{3}$ for Q-mass class. One of the most common classes, which is selected for the current case study, is the large conventional. The average particulars for this class can be listed in Table 2 [35]. The maximum design draft is limited to $12 \mathrm{~m}$ due to the available port facilities. This results in quite high beam to draft ratio above 4.0. For this case, twin-screw propulsion system will reduce the required main engine power up to $9.0 \%$ compared with the single screw system. In addition, most of the LNG carrier propulsion engines are designed to 
use BOG from the cargo. The case study ship is assumed to export the LNG from Qatar, the largest exporter in the world, to Japan, the largest importer of LNG in 2017 [36, 37]. The average distance from Qatar to Japan is 6347 nautical miles. The tip time will be 26 days and 10.0 hours, using ship speed of 20.0 knots [38]. The number of trips per year is assumed to be 10.0 .

Table 2 Large conventional LNG carrier using twin-screw propeller average particulars

\begin{tabular}{ll}
\hline LNG carrier item & Particulars \\
\hline Type & Membrane Type \\
Ship size, LNG capacity & $150,000 \mathrm{~m}^{3}$ \\
Scantling draught & $12.3 \mathrm{~m}$ \\
Length overall & $288.0 \mathrm{~m}$ \\
Length between pp & $275 \mathrm{~m}$ \\
Breadth & $44.2 \mathrm{~m}$ \\
Design draught & $11.6 \mathrm{~m}$ \\
Average design speed & $20.0 \mathrm{Knots}$ \\
Power (MCR) & $2 \times 14,900 \mathrm{~kW}$ \\
\hline
\end{tabular}

\section{Environmental and economic modeling}

The emission of pollutant $(\mathrm{j})$ over a complete ship trip in tones $\left(\mathrm{m}_{\mathrm{e}, \mathrm{j}}\right)$ can be calculated using Eq. (1) [39, 40].

$$
m_{e, j}=P \cdot L \cdot T \cdot E F_{j}
$$

where, $P$ is the engine power in $\mathrm{kW}$ with its load factors $(L), T$ is the trip time in hours, and $E F_{j}$ is the emission factor of the pollutant (j) expressed in ton $/ \mathrm{kWh}$. Table 3 shows the different emission factors $\left(E F_{j}\right)$ for gas turbine $(\mathrm{GT})$, steam turbine (ST), slow and medium speed marine diesel engine (SSDE and MSDE) operating on heavy fuel oil (HFO), marine gas oil (MGO), and natural gas (NG) [14, 40-45].

NG can be used in a dual fuel mode in LNG carriers. The emission factor in case of using dual fuel engine $\left(\mathrm{EF}_{\mathrm{DF}, \mathrm{j}}\right)$ for each pollutant emission can be calculated using Eq. (2).

$$
E F_{D F, j}=x_{m} E F_{m}+x_{N G} E F_{N G}
$$

where, $x_{m}$ and $x_{N G}$ are the percentages of the main fuel and the NG fuels in dual-fuel engine (DFE), $E F_{m}$ and $E F_{N G}$ are the emission factors in $\mathrm{g} / \mathrm{kWh}$ for the main and the natural gas engines.

The percentage of the BOG in the dual fuel mode during one trip can be calculated using the boil-off rate (BOR). It represents the quantity of the evaporated LNG per day expressed as a percentage of the total cargo (\%/day) [46, 47]. BOR can be calculated using Eq. (3).

$$
B O R=\left(\frac{Q}{H_{\text {latent }}} \times 3600 \times 24\right) \times \frac{100}{\rho_{L_{2}} V_{c \arg o}}
$$


where, $Q$ is the heat exchange in LNG tanks in $\mathrm{kW}, \rho$ is the density of LNG in $\mathrm{kg} / \mathrm{m}^{3}$, and $H_{\text {latent }}$ is the heat of vaporization in $\mathrm{kJ} / \mathrm{kg}$. The average $B O R$ values for new LNG tankers range from 0.10 to $0.15 \%$ /day for loaded voyage and from 0.06 to $0.10 \%$ /day for ballast voyage [48-50].

Table 3 Emission factors for different LNG propulsion options in $\mathrm{g} / \mathrm{kWh}$

\begin{tabular}{lllll}
\hline \multirow{2}{*}{ Engine type } & Fuel used & \multicolumn{3}{l}{ Emission factors $(\mathrm{g} / \mathrm{kWh})$} \\
\cline { 3 - 5 } & & $\mathrm{NO}_{\mathrm{x}}$ & $\mathrm{SO}_{\mathrm{x}}$ & $\mathrm{CO}_{2}$ \\
\hline \multirow{2}{*}{$\mathrm{SSDE}$} & $\mathrm{HFO}(2.7 \% \mathrm{~S})$ & 17 & 12.9 & 550 \\
\hline \multirow{3}{*}{ MSDE } & $\mathrm{HFO}(2.7 \% \mathrm{~S})$ & 14.00 & 11.24 & 677.91 \\
& $\mathrm{MGO}(0.1 \% \mathrm{~S})$ & 13.20 & 0.40 & 646.08 \\
& $\mathrm{NG}$ & 2.16 & 0.0 & 548.2 \\
\hline \multirow{2}{*}{ COGAS } & $\mathrm{MGO}(0.1 \% \mathrm{~S})$ & 14 & 0.0 & 590 \\
& $\mathrm{NG}$ & 0.9 & 0.0 & 510 \\
\hline \multirow{2}{*}{ ST } & $\mathrm{HFO}(2.7 \% \mathrm{~S})$ & 11.0 & 1.0 & 930 \\
& $\mathrm{NG}$ & 0.4 & 0.0 & 241 \\
\hline \multirow{2}{*}{$\mathrm{UST}$} & $\mathrm{HFO}(2.7 \% \mathrm{~S})$ & 8.25 & 0.75 & 697.5 \\
\cline { 2 - 5 } & $\mathrm{NG}$ & 0.3 & 0.0 & 180.75 \\
\hline
\end{tabular}

The emission factors for LNG ship should be compared with the required IMO emission rates for $\mathrm{NO}_{x}, \mathrm{SO}_{x}$ and $\mathrm{CO}_{2}$. For $\mathrm{NO}_{x}$ emissions, the emission limit equations, expressed in $\mathrm{g} / \mathrm{kWh}$, of the applicable Tier III values, only for NECA ( $\mathrm{NO}_{\mathrm{x}}$ Emission control areas ), based on the rated engine speeds in rpm are shown in Eq. (4) [28, 40, 44, 51-53].

$$
N O_{x, \text { Tier III }}=\left\{\begin{array}{ll}
3.4 & \text { for } r p m<130 \\
9 \times r p m^{-0.2} & \text { for } 130 \leq r p m<2000 \\
2.0 & \text { for } r p m \geq 2000
\end{array}\right\}
$$

$\mathrm{SO}_{\mathrm{x}}$ emissions are limited by the sulfur percent in the used marine fuel. For 2020 IMO $\mathrm{SO}_{x}$ regulations, the permitted sulfur percent in the fuels is $0.5 \%$ [40, 51, 54-56]. On the other hand, greenhouse gas (GHG) emissions especially $\mathrm{CO}_{2}$ emissions are limited by IMO through introducing Energy Efficiency Design Index (EEDI) and Energy Efficiency Operational Indicator (EEOI) [57]. The calculated EEDI should be compared with the reference values for EEDI in three phases according to the ship type. For LNG ship, the reference and the calculated values for the EEDI are based on the ship deadweight (DWT) as expressed in Eqs. (5) and (6) [46, 47, 58-62].

$$
\begin{aligned}
E E D I_{\text {ref. }}= & 2253.7 \times D W T^{0.474} \\
\text { EEDI } I_{\text {cal. }}= & \frac{P_{M E} \times\left(C_{F, \text { pilot }} \times S F C_{M E, \text { pilot }}+C_{F, \text { fuel }} \times S F C_{M E, \text { fuel }}\right)}{f_{c} \times V_{\text {ref }} \times D W T} \\
& +\frac{P_{A E} \times\left(C_{F, p i l o t} \times S F C_{A E, p i l o t}+C_{F, \text { fuel }} \times S F C_{A E, \text { fuel }}\right)}{f_{c} \times V_{\text {ref }} \times D W T}
\end{aligned}
$$


where, $P_{M E}$ is the is the main engine power, it can be calculated using Eq. (7). $P_{A E}$ is the auxiliary power required to operate the accommodation of crew and the main engine, $V_{\text {ref }}$ is the reference ship speed in knots, $\mathrm{C}_{\mathrm{F}}$ is the fuel conversion factor to $\mathrm{CO}_{2}$ emissions. IF LNG carrier uses reliquefaction plant, $\mathrm{P}_{\mathrm{AE}}$ will include $\mathrm{P}_{\mathrm{AE} \text {,Reliq }}$ for the EEDI calculation, $\mathrm{COP}_{\text {Reliq. }}$ and $\mathrm{COP}_{\text {cooling }}$ are the coefficients of performance for the reliquefaction and cooling plants, respectively as expressed in Eqs. (8) - (10) [47, 63, 64].

$$
\begin{aligned}
& P_{M E}=0.75 \times M C R \\
& P_{A E}=0.025 \times M C R+250+P_{A E, \text { Reliq. }} \\
& P_{A E, \text { Reliq. }}=V_{c \operatorname{argo}} \times B O R \times C O P_{\text {Reliq. }} \\
& C O P_{\text {Reliq. }}=\frac{\rho_{\mathrm{LH}_{2}} \times H_{\text {latent }}}{24 \times 3600 \times C O P_{\text {cooling }}}
\end{aligned}
$$

The cubic capacity correction factor $\left(f_{c}\right)$, used in Eq. (6), equals 1.0 except for directdiesel-driven LNG carrier. It can be calculated using Eq. (11), where R is the ship deadweight divided by the cargo capacity.

$$
f_{c}=R^{-0.56}
$$

From economic point of view, the annual cost for installation each propulsion system (AC) depends on the capital cost value (CC), the average expected working years (n), and the interest rate (i) [65]. AC can be calculated using Eq. (12).

$$
A C=C C \times \frac{i(1+i)^{n}}{(1+i)^{n}-1}
$$

In addition, the annual fuel saving cost due to using $\mathrm{NG}\left(\mathrm{FS}_{\mathrm{NG}}\right)$ in dual fuel mode onboard LNG carrier can be calculated using Eq. (13).

$$
F S_{N G}=\left(C_{D O}-C_{D F}\right) \times(1 \pm P I)^{n}
$$

where, $\mathrm{C}_{\mathrm{DO}}$ and $\mathrm{C}_{\mathrm{DF}}$ are the diesel fuel and the dual-fuel costs, respectively. (PI) is the annual fuel price change percent over the working years (n) of the ship life cycle.

Finally, the annual cost-effectiveness of each propulsion system (ACE) for reducing a pollutant emission (j) after using dual fuel engine can be calculated using Eq. 14 [40, 42].

$$
A C E_{j}=\frac{A C+O C}{E R_{j}}
$$

where, OC is the operating and maintenance costs for the propulsion system in $\$ / y e a r . E_{j}$ is the annual emission reduction in $(\mathrm{j})$ after using dual fuel engine expressed in ton/year.

\section{Results and discussion}

In this section, the environmental results for different LNG carrier propulsion options using HFO and MGO are discussed. In addition, the economic and cost-effectiveness analysis for the dual fuel operated propulsion options, using NG, are calculated. 


\subsection{Environmental results}

Fuel efficiency not only affects the operating costs of the marine propulsion power plant but also extremely influence the emitted exhaust gas emissions. Although the efficiency of steam power plant is lower than internal combustion engines, UST with reheating has improved the efficiency of the steam cycle to a comparative level. Typical efficiencies of $157,000 \mathrm{~m}^{3}$ LNG carrier using ST, UST, SSDE with reliquefaction plant, dual fuel MSDE, and COGAS power plants are 35\%, 41\%, 40\%, 42\%, and 50\%, respectively [2, 29, 66]. UST emission factors are reduced by $25 \%$ compared with the simple GT cycle [14]. LNG carrier propulsion systems can fulfill the required levels of $\mathrm{NO}_{\mathrm{x}}$ and $\mathrm{SO}_{\mathrm{x}}$ emission levels set by IMO depending on the used plant and the fuel type. Fig. 2 shows the relative $\mathrm{NO}_{\mathrm{x}}$ and $\mathrm{SO}_{\mathrm{x}}$ emissions from the five most used marine power plants for LNG carriers using HFO and MGO. Any observed power plant satisfies IMO standards (for both $\mathrm{SO}_{\mathrm{x}}$ and $\mathrm{NO}_{\mathrm{x}}$ ) if the relative emissions are $100 \%$ or lower. In order to calculated the emission levels set by IMO, the average rpm for ST, SSDS, DFDE, GT is assumed to be $3500 \mathrm{rpm}, 85 \mathrm{rpm}, 750 \mathrm{rpm}$, and $3600 \mathrm{rpm}$, respectively [67-69]. It can be noted from Fig. 2 that all power plants could comply with $\mathrm{IMO}-\mathrm{SO}_{\mathrm{x}}$ emission levels using MGO. In contrast, all power plants cannot achieve these levels using HFO. On the other hand, all power plants cannot fulfill the required IMO- $\mathrm{NO}_{\mathrm{x}}$ emission levels.
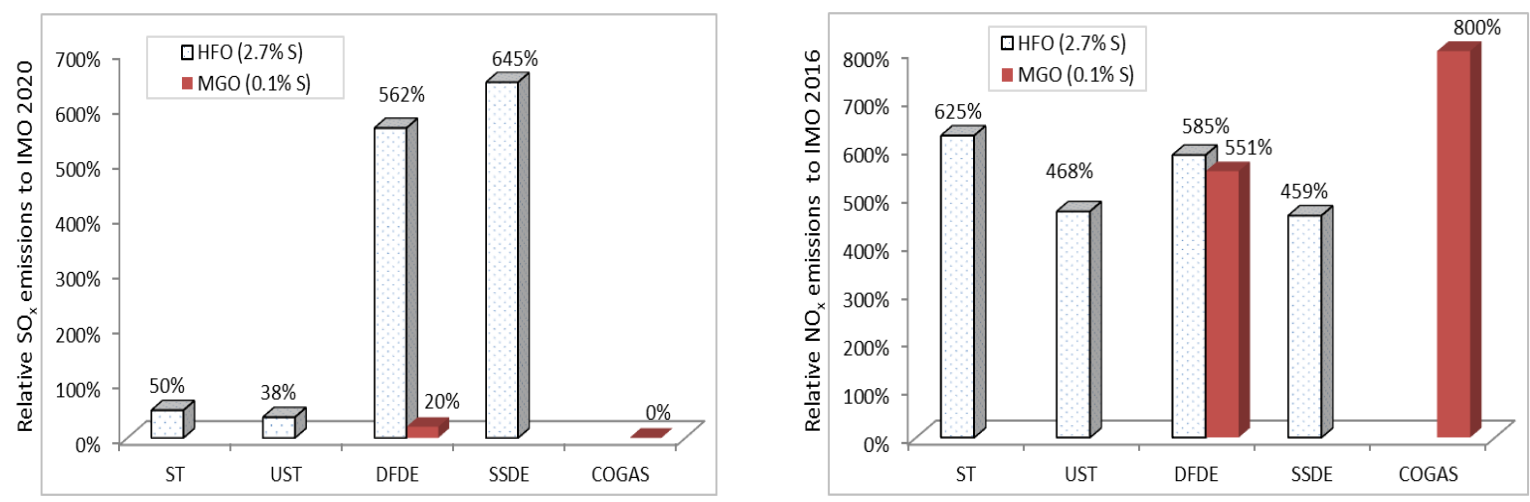

Fig. $2 \mathrm{NO}_{\mathrm{x}}$ and $\mathrm{SO}_{\mathrm{x}}$ emissions comparison using $\mathrm{HFO}$ and $\mathrm{MGO}$

Due to the strict IMO regulations that limit the exhaust gas emissions from ships, it is an important factor to consider using the BOG as a secondary fuel in LNG carriers during the design process. This will help in reducing the exhaust gas emissions. From section 2, SSDE propulsion option use BOG either in a reliquefaction plant or in GCU. Thus, it is not included in the dual fuel mode. Fig. 3 shows $\mathrm{NO}_{\mathrm{x}}$ and $\mathrm{SO}_{\mathrm{x}}$ emissions from $\mathrm{LNG}$ propulsion plants using HFO and MDO in dual fuel mode using BOR of $0.15 \% /$ day for the loaded voyage [4850]. The share percentages of these BOG in LNG propulsion fuel is calculated based on the fact that each cubic meter of diesel oil consumption is equivalent for $1197 \mathrm{~m}^{3}$ of NG [44]. In addition, the volume of NG is reduced by 600 times when converted to the liquid state [40, 70]. The percentages of BOG in dual fuel mode range from $55.47 \%$ to $79.49 \%$ using ST and COGAS, respectively for the case study. Using BOG, both $\mathrm{NO}_{\mathrm{x}}$ and $\mathrm{SO}_{\mathrm{x}}$ emission rates cannot be complied with IMO regulations, using different LNG propulsion options, as shown in Fig. 3. 

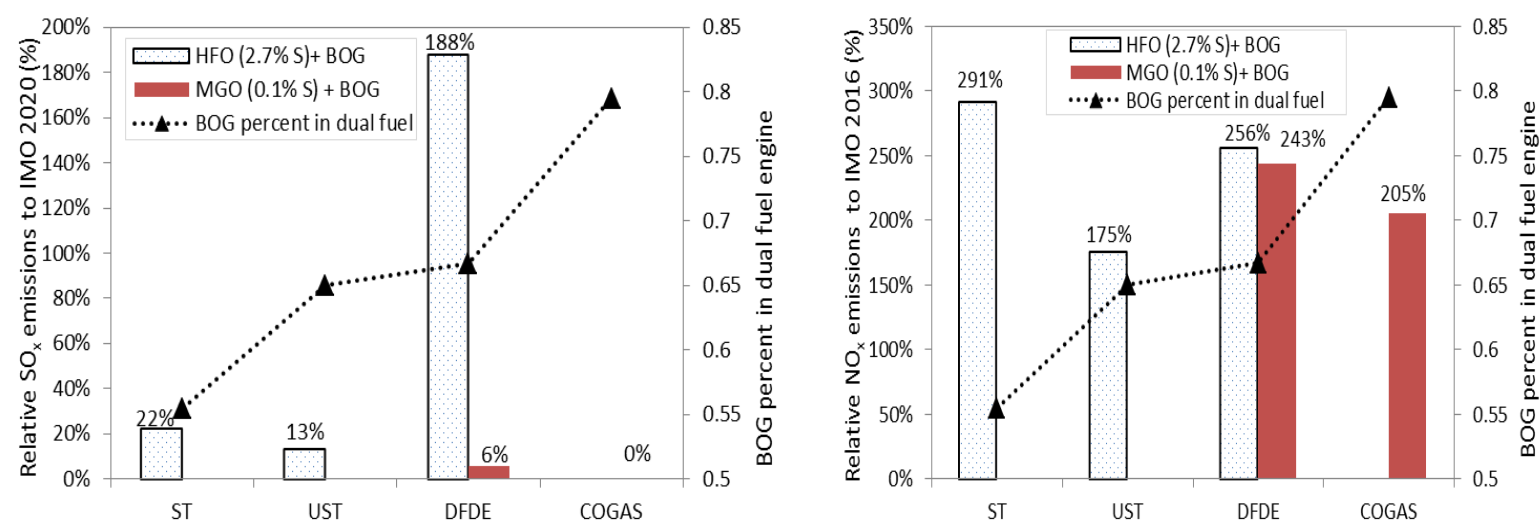

Fig. $3 \mathrm{NO}_{\mathrm{x}}$ and $\mathrm{SO}_{\mathrm{x}}$ emissions comparison using the main-engine fuel and BOR of 0.15\%/day

From Fig. 3, NG percent can be increased in the dual fuel mode to reduce the exhaust gas emissions to the accepted rates set by IMO for $\mathrm{NO}_{\mathrm{x}}$ and $\mathrm{SO}_{\mathrm{x}}$ emissions. The minimum $\mathrm{NG}$ percentages in dual fuel mode for the different propulsion options are $87.5 \%, 82 \%, 98.5 \%$ and $94 \%$ to achieve the required IMO values for $\mathrm{NO}_{\mathrm{x}}$ and $\mathrm{SO}_{\mathrm{x}}$ emissions using ST, UST, DFDE, and COGAS, respectively as shown in Fig. 4. The shares of BOG in these percentages are $55.47 \%, 65.0 \%, 66.67 \%$, and $79.49 \%$, respectively. Moreover, using dual fuel will reduce $\mathrm{CO}_{2}$ emissions because of the reduced carbon content in $\mathrm{NG}$ compared with liquid marine fuels. Fig. 4 shows the relative $\mathrm{CO}_{2}$ emissions of different LNG carrier propulsion systems using dual fuel propulsion systems with the accepted $\mathrm{NO}_{\mathrm{x}}$ and $\mathrm{SO}_{\mathrm{x}}$ emission levels set by IMO $\mathrm{CO}_{2}$ emissions from ships are one of the major concerns of the IMO due to its bad influence on the global warming. The highest and the lowest $\mathrm{CO}_{2}$ emission reduction percentages are achieved by the ST and the COGAS with percentages of $64.83 \%$ and $12.75 \%$, respectively. These reductions in $\mathrm{CO}_{2}$ emissions will improve the energy efficiency of the ship through calculating EEDI and EODI [62].

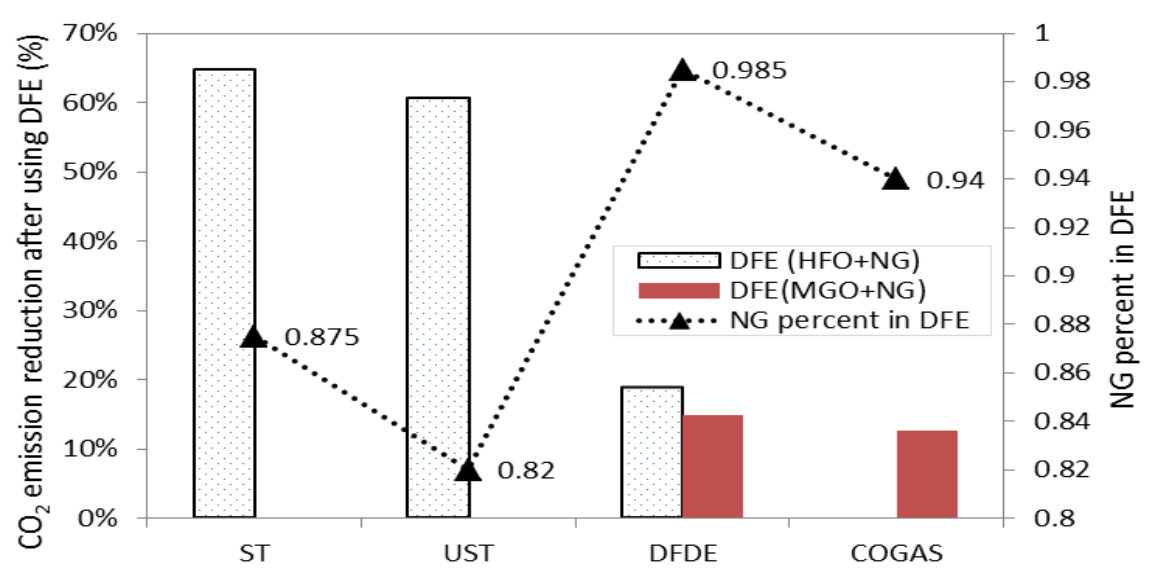

Fig. $4 \mathrm{CO}_{2}$ emissions comparison for different $\mathrm{LNG}$ propulsion options

$\mathrm{CO}_{2}$ emissions presented in Fig. 4 have to be complied with the required IMO regulations. In addition, the newly built LNG carriers should be designed to be energy efficient to reduce carbon dioxide emissions through calculating the energy efficiency design index (EEDI). It depends on the type of the ship, the main and auxiliary engines, the construction, and the used fuel. It calculates the amount of $\mathrm{CO}_{2}$ emissions per unit distance of cargo transportation. Fig. 5 shows the permitted $\mathrm{CO}_{2}$ emissions set by IMO in $\mathrm{gCO}_{2} /$ ton-NM (Required EEDI). The values of the EEDI for LNG carriers depend on the ship deadweight presented in three phases according to the ship built year. The base line values will be reduced 
by 20 and 30 percentages in the second and the third phases in the years 2020 and 2025 , respectively.

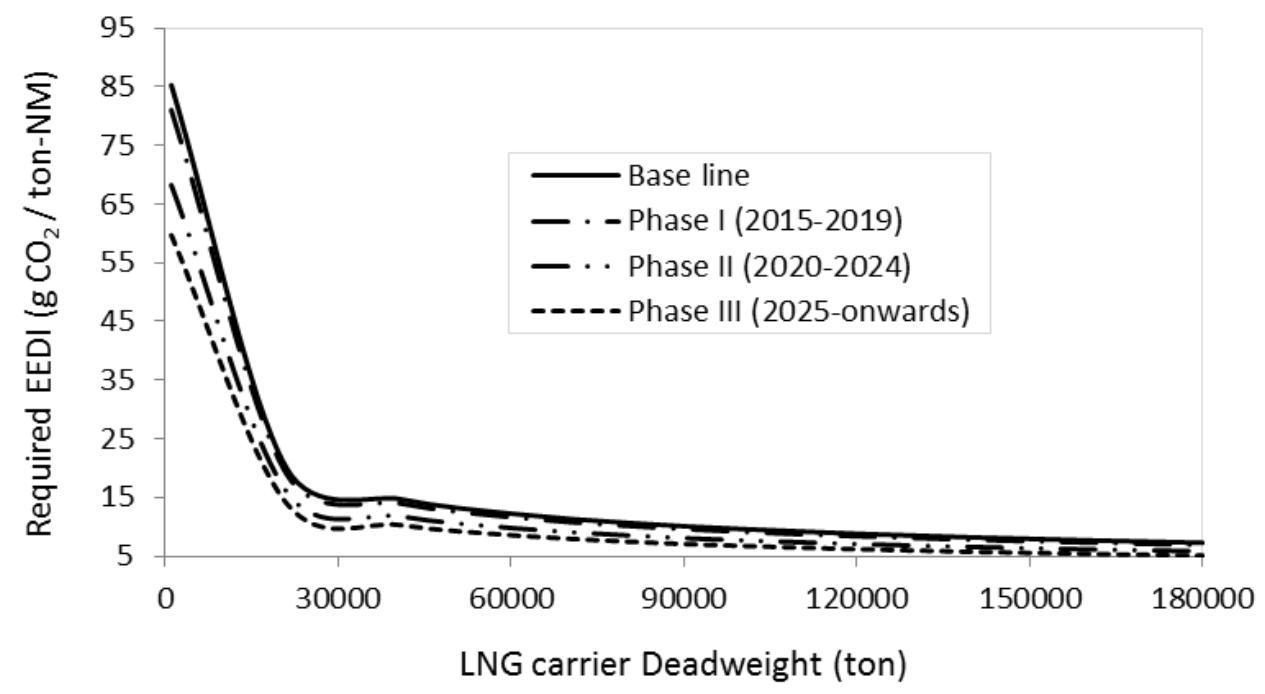

Fig. 5 EEDI values for LNG carriers recommended by IMO in three phases

\subsection{Economic and cost-effectiveness results}

The economic feasibility of LNG carrier propulsion options can be judged using the total costs for each option and its environmental impact assessment. The total costs include the initial installation and operational costs. The initial costs per unit power for ST, DFDE, SSDE, and COGAS are $136 \$ / \mathrm{kW}, 667 \$ / \mathrm{kW}, 940 \$ / \mathrm{kW}$, and $1410 \$ / \mathrm{kW}$, respectively [47, $71,72]$. For LNG carrier of $150,000 \mathrm{~m}^{3}$ capacity, the initial installations costs for ST, DFDE, SSDE, and COGAS propulsion systems are 4.05 MUS\$, 1.99 MUS\$, 2.80 MUS\$, and 4.20 MUS\$, respectively. On the other hand, the fuel consumption cost is the highest percent of the operating costs over the life cycle of the propulsion power plants [47]. The prices of HFO, MGO, and NG are $556 \$ / \mathrm{m}^{3}, 882 \$ / \mathrm{m}^{3}$, and $0.3047 \$ / \mathrm{m}^{3}$, respectively [73-75]. The cost of HFO consumptions per trip are 2.99 MUS\$, 2.55 MUS\$, 2.49 MUS\$, and 2.62 MUS\$ for the case study propulsion options using ST, UST, DFDE, and SSDE, respectively. On the other hand, the costs of MGO fuel per trip are 3.94 MUS\$ and 3.31 MUS\$ for DFDE and COGAS, respectively. Based on 2018 fuel oil and NG prices using dual fuel engines will save in the fuel consumption due to the low price of NG compared with the diesel oil prices. Fig. 6 illustrates the fuel saving cost per trip for different LNG propulsion options operated with dual fuel engines with different NG percentages. The highest fuel saving cost is 2.79 MUS\$/trip for DFDE propulsion system operated with MGO. In contrast, the lowest fuel saving cost is 1.0 MUS\$/trip for UST operated with dual HFO and NG fuels. 


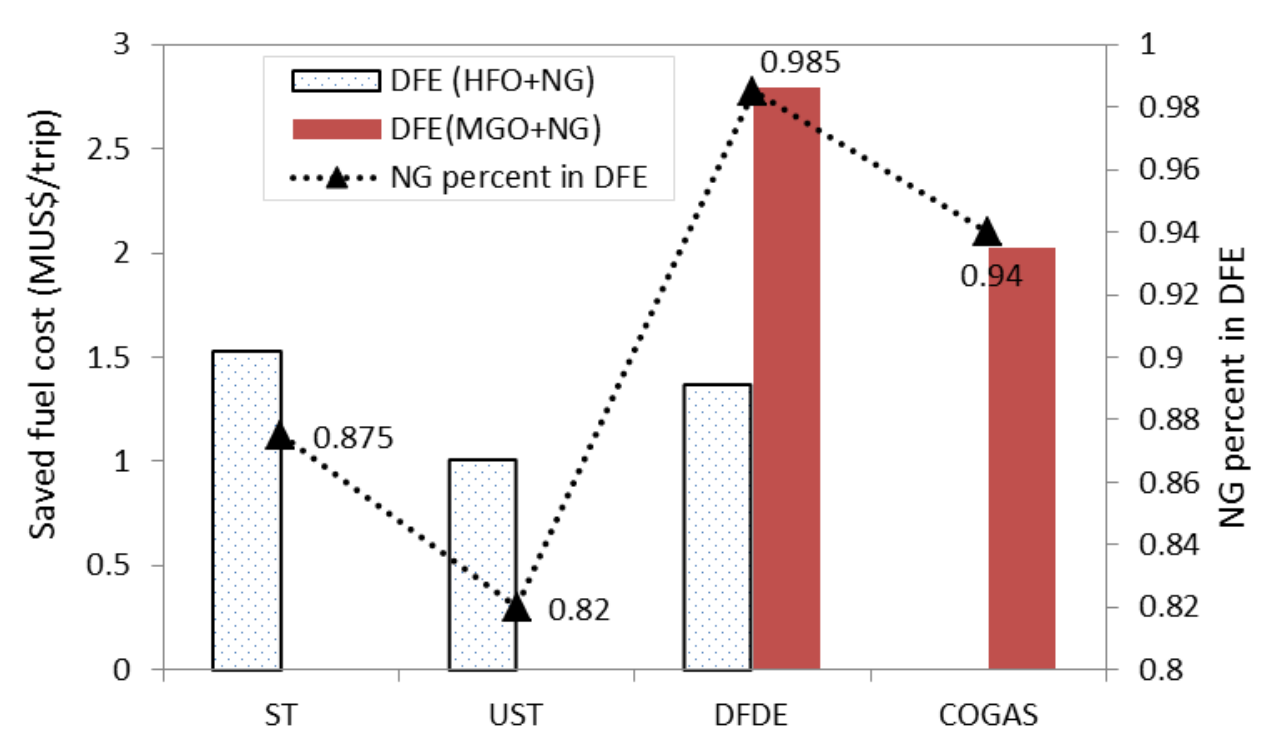

Fig. 6 Fuel saving cost per trip using dual fuel propulsion options for LNG carrier

The economic assessment for LNG carrier propulsion options complied with IMO regulations using dual fuel mode can be evaluated using the total annual costs for each option. Fig. 7 shows the total annual costs and emission reduction percentages for ST, UST, DFDE, and COGAS propulsion options operated in dual fuel mode. The total annual costs for ST, UST, and DFDE, propulsion options operated with HFO-NG dual fuel are 15.05 MUS\$, 15.90 MUS\$, and 13.38 MUS\$, respectively. The reduction percentages in $\mathrm{NO}_{\mathrm{x}}$ emissions for these options compared with the HFO operated engines are $84.32 \%, 79.02 \%$, and $83.3 \%$, respectively. For $\mathrm{SO}_{\mathrm{x}}$ emissions, the reduction percentages will be $87.5 \%, 82 \%, 98.5 \%$, respectively. On the other hand, the total annual costs for MGO-NG dual fuel operated COGAS propulsion system is 17.38 MUS\$ with zero $\mathrm{SO}_{\mathrm{x}}$ emissions and $87.96 \% \mathrm{NO}_{\mathrm{x}}$ emission reduction percent.

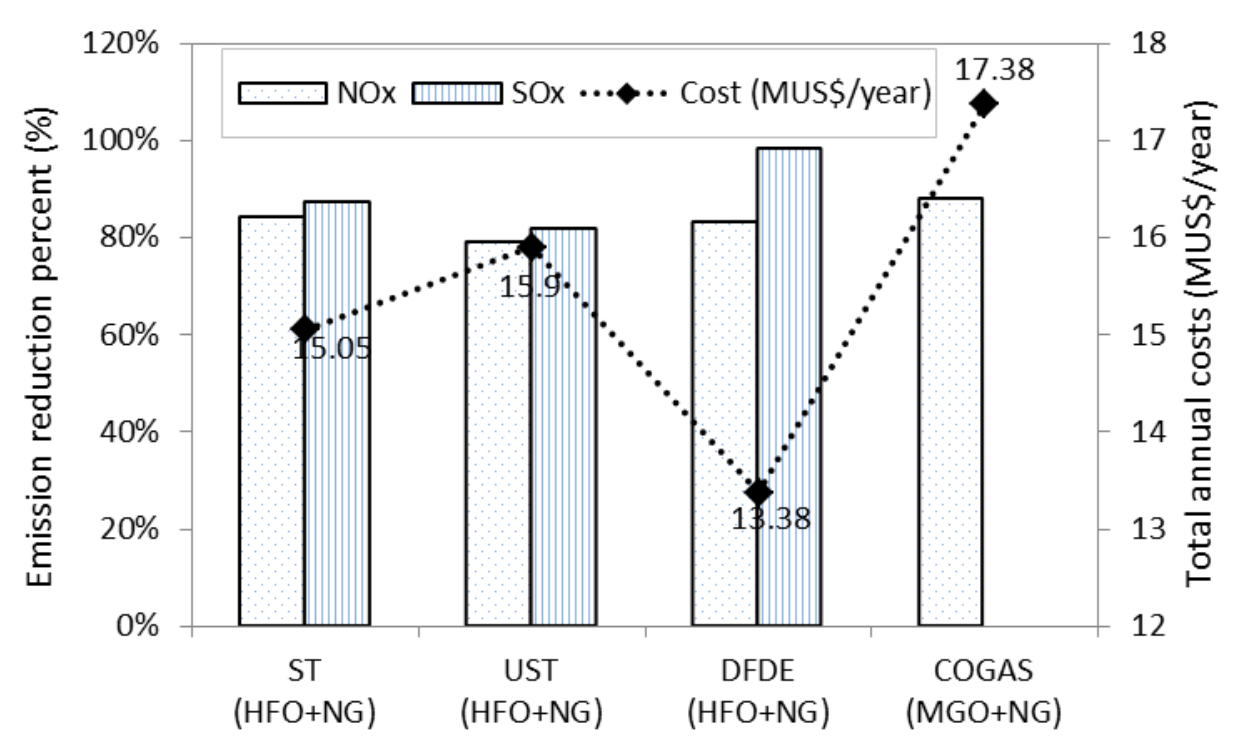

Fig. 7 Total annual costs and emission reduction percentages for dual-fuel propulsion options

From Fig. 7, DFDE operated with dual HFO and NG is the most economic and emission compliance propulsion option for large conventional LNG carrier. The annual costs for capital 
cost recovery and the annual fuel saving costs for DFDE, compared with the HFO operated engine, are presented in Fig. 8. The annual costs are calculated over the assumed ship life cycle of 28 years $[40,76]$. The annual costs for capital cost recovery and fuel saving, at the end of the ship life cycle, will be 2.14 MUS\$ and 23.80 MUS\$, assuming annual interest rate of $10 \%$ and fuel price increment of $2 \%$, respectively.
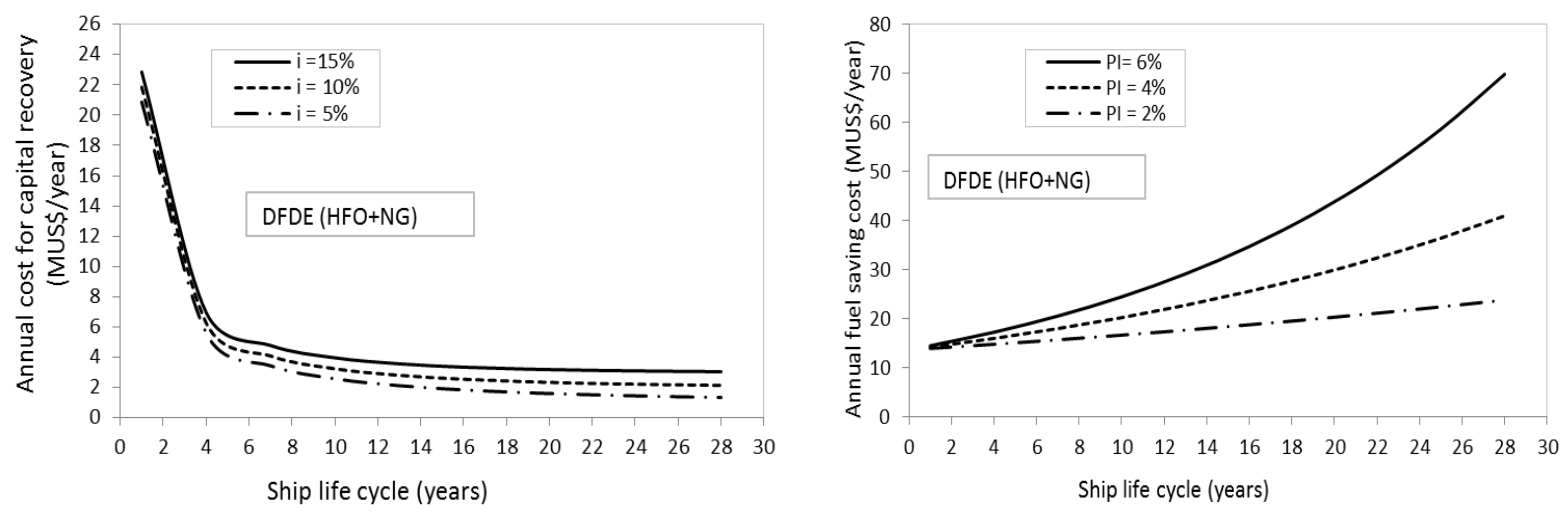

Fig. 8 Annual costs for DFDE propulsion option over LNG carrier life cycle

In order to combine the environmental benefits and the economic analysis for the four propulsion options for LNG carriers achieved IMO emission requirements, the costeffectiveness for each reduction in pollutant emissions is calculated. It assesses the economic benefits for the total costs of each propulsion option in terms of its environmental consequences. The cost effectiveness is calculated for the three most economic propulsion options achieved IMO $\mathrm{NO}_{\mathrm{x}}$ and $\mathrm{SO}_{\mathrm{x}}$ emission requirements. Fig. 9 compares the costeffectiveness for reducing $\mathrm{NO}_{\mathrm{x}}, \mathrm{SO}_{x}$, and $\mathrm{CO}_{2}$ emissions after using dual fuel propulsion options for DFDE, UST, and COGAS at annual interest rate of 10\%. On the Fig. 9 the lower value is better. The most economic propulsion option is the DFDE operated with dual HFO and NG fuels. It reduces $\mathrm{NO}_{\mathrm{x}}, \mathrm{SO}_{\mathrm{x}}$, and $\mathrm{CO}_{2}$ emissions with annual cost-effectiveness of 6.07 $\$ / \mathrm{kg}, 6.39 \$ / \mathrm{kg}$, and $0.55 \$ / \mathrm{kg}$, respectively.

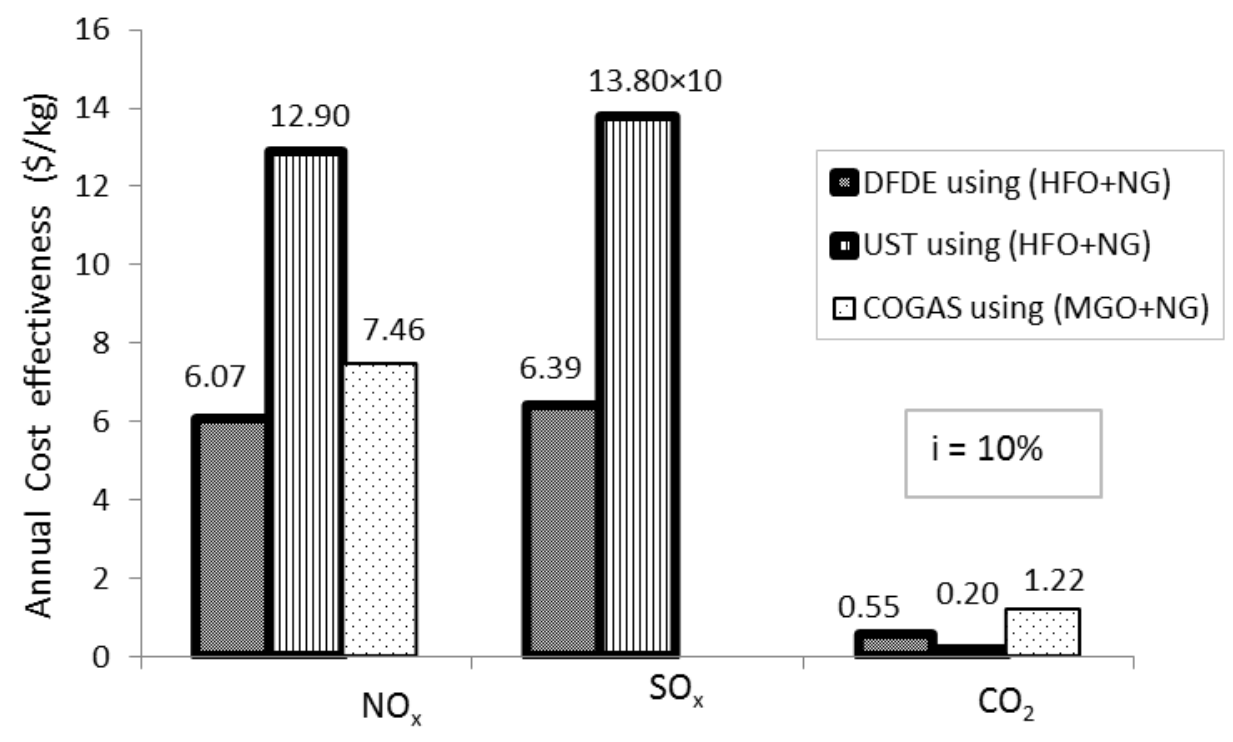

Fig. 9 The annual cost-effectiveness for reducing $\mathrm{NO}_{x}, \mathrm{SO}_{\mathrm{x}}$ and $\mathrm{CO}_{2}$ emissions 


\section{Conclusions}

Environmental, economic and cost-effectiveness analysis for the available LNG carrier propulsion options operated with heavy fuel oil (HFO), marine gas oil (MGO), and dual fuel (with natural gas) were investigated. These options include steam turbine (ST), ultra steam turbine (UST), dual fuel diesel engine (DFDE), slow speed diesel engine (SSDE), and combined gas and steam (COGAS) propulsion systems. The used fuel for all the propulsion options is the HFO except COGAS operates with MGO and DFDE uses both HFO and MGO. The main conclusions for large conventional LNG carrier with a capacity of $150,000 \mathrm{~m}^{3}$ are:

- From environmental point of view, ST, UST, DFDE, and COGAS propulsion options can fulfill the required IMO values for $\mathrm{NO}_{\mathrm{x}}$ and $\mathrm{SO}_{\mathrm{x}}$ emissions using $\mathrm{NG}$ percentages in dual fuel mode with percentages of $87.5 \%, 82 \%, 98.5 \%$ and $94 \%$, respectively. The shares of boil off gas (BOG) in these percentages are 55.47\%, 65.0\%, 66.67\%, and $79.49 \%$, respectively. The highest $\mathrm{CO}_{2}$ emission reduction percent is achieved by the UST with a reduction percent of $64.83 \%$ from the same cycle without NG.

- From economic point of view, Using BOG as fuel will save the cost of fuel consumption by $19.08 \%, 22.35 \%, 22.9 \%$ and $46.62 \%$ for ST, UST, DFDE and COGAS propulsion options, respectively. Increasing NG percentages to achieve the $\mathrm{NO}_{\mathrm{x}}$ and the $\mathrm{SO}_{\mathrm{x}}$ emission rates set by IMO for ST, UST, and COGAS propulsion options will save the dual fuel cost by 1.53 MUS\$/year, 1.0 MUS\$/year, and 2.02 MUS\$/year, respectively. On the other hand, DFDE operated with dual HFO and NG is the most economic propulsion option with total annual costs of 13.38 MUS\$ and emission reduction percentages of $83.30 \%, 98.50 \%$, and $18.85 \%$ for $\mathrm{NO}_{\mathrm{x}}, \mathrm{SO}_{\mathrm{x}}$ and $\mathrm{CO}_{2}$ emissions, respectively.

- From cost-effectiveness point of view, the total annual costs for ST, UST, and DFDE, propulsion options operated with HFO-NG dual fuels are 15.05 MUS\$, 15.90 MUS\$, and 13.38 MUS\$, respectively. On the other hand, the total annual costs for MGO-NG dual fuel operated COGAS propulsion system is 17.38 MUS\$. DFDE operated with $\mathrm{HFO}$ and NG fuels is the most economic and IMO emission compliance propulsion option. It reduces $\mathrm{NO}_{\mathrm{x}}, \mathrm{SO}_{\mathrm{x}}$, and $\mathrm{CO}_{2}$ emissions with annual cost-effectiveness of 6.07 $\$ / \mathrm{kg}, 6.39 \$ / \mathrm{kg}$, and $0.55 \$ / \mathrm{kg}$, respectively.

\section{Nomenclature}

$\begin{array}{ll}\text { AC } & \text { Annual cost for installation, \$/year } \\ \text { BOR } & \text { Boil-off gas rate, \%/day } \\ \mathrm{C} & \text { Annual fuel cost, \$/year } \\ \mathrm{C}_{\mathrm{F}} & \text { Fuel conversion factor to } \mathrm{CO}_{2} \text { emissions } \\ \mathrm{COP} & \text { Coefficient of performance } \\ \text { EEDI } & \text { Energy Efficiency Design Index, } \mathrm{gCO}_{2} / \mathrm{ton}-\mathrm{NM} \\ \mathrm{EF} & \text { Engine emission factor, } \mathrm{kg} / \mathrm{kWh} \\ \mathrm{ER} & \text { Emissions reduction percentage, } \% \\ \text { FS } & \text { Fuel saving cost, } \$ / \text { year } \\ \text { FSE } & \text { Fuel saving cost-effectiveness, } \$ / \mathrm{ton} \\ \mathrm{i} & \text { Annual interest rate, } \% \\ \mathrm{~L} & \text { Engine load percent in ship modes } \\ \text { LCV } & \text { Lower calorific value, } \mathrm{kJ} / \mathrm{kg}\end{array}$

\section{Abbreviations}

$\begin{array}{ll}\text { BOG } & \text { Boil-off gas } \\ \mathrm{CO}_{2} & \text { carbon dioxide } \\ \text { COGAS } & \text { Combined gas and steam } \\ \text { DFDE } & \text { Dual fuel diesel engine } \\ \text { GCU } & \text { Gas combustion unit } \\ \text { GT } & \text { Gas turbine } \\ \text { HFO } & \text { Heavy fuel oil } \\ \text { IMO } & \text { International Maritime Organization } \\ \text { LNG } & \text { Liquefied natural gas } \\ \text { MGO } & \text { Marine gas Oil } \\ \text { MSDE } & \text { Medium speed marine diesel engine } \\ \text { NG } & \text { Natural gas } \\ \text { NO } & \text { Nitrogen Oxides Emissions }\end{array}$




$\begin{array}{llll}\mathrm{m} & \text { Mass, } \mathrm{kg} & \mathrm{S} & \text { Sulfur } \\ \mathrm{MCR} & \text { Maximum continuous rating of the engine, } \mathrm{kW} & \mathrm{SSDE} & \text { Slow speed marine diesel engine } \\ \mathrm{n} & \text { Expected ship working years } & \mathrm{SO}_{\mathrm{x}} & \text { Sulfur Oxides Emissions } \\ \mathrm{P} & \text { Engine power at maximum continuous rating, } \mathrm{kW} & \mathrm{ST} & \text { Steam turbine } \\ \mathrm{PI} & \text { Annual fuel price change percent, } \% & \mathrm{UST} & \text { Ultra steam turbine } \\ \mathrm{SFC} & \text { Specific fuel consumption, g/kWh } & \\ \mathrm{T} & \text { Engine running time, } \mathrm{h} & \\ \mathrm{V}_{\text {ref }} & \text { Reference ship speed, knots } & \\ \mathrm{x} & \text { Fuel percentage in dual fuel engine } & \\ \mathrm{Subscript} & & \\ \mathrm{DF} & \text { Dual fuel diesel engine } & \\ \mathrm{DO} & \text { Diesel oil } & \\ \mathrm{j} & \text { Type of pollutant, } \mathrm{SO}_{\mathrm{x}}, \mathrm{NO}_{\mathrm{x}} \text { or } \mathrm{CO}_{2} & \\ \mathrm{~m} & \text { Engine main fuel } & \\ \mathrm{NG} & \text { Natural gas } & \\ \text { Reliq. } & \text { Reliquefaction } & \end{array}$

\section{REFERENCES}

[1] Schebach, K.e.-a., The next generation of large LNG carriers, in Proc. of the 9th International Marine Design Conference, 15-19 May 2006, Ann Arbor,MI2006.

[2] Sinha, R.P. and W.M.N.W. Nik, Investigation of propulsion system for large LNG ships, in IOP Conference Series: Materials Science and Engineering, Mater. Sci. Eng. 36012004. https://doi.org/10.1088/1757-899X/36/1/012004

[3] Kumar, S., et al., Current status and future projections of LNG demand and supplies: A global prospective. Energy Policy, 2011. 39(7): p. 4097-4104. https://doi.org/10.1016/j.enpol.2011.03.067

[4] Maxwell, D. and Z. Zhu, Natural gas prices, LNG transport costs, and the dynamics of LNG imports. Energy Economics, 2011. 33(2): p. 217-226. https://doi.org/10.1016/j.eneco.2010.06.012

[5] Aguilera, R.F. and R. Aguilera, World natural gas endowment as a bridge towards zero carbon emissions. Technological Forecasting and Social Change, 2012. 79(3): p. 579-586. https://doi.org/10.1016/j.techfore.2011.09.004

[6] Querol, E., et al., Boil off gas (BOG) management in Spanish liquid natural gas (LNG) terminals. Applied Energy, 2010. 87(11): p. 3384-3392. https://doi.org/10.1016/j.apenergy.2010.04.021

[7] Kurle, Y.M., S. Wang, and Q. Xu, Simulation study on boil-off gas minimization and recovery strategies at LNG exporting terminals. Applied Energy, 2015. 156: p. 628-641. https://doi.org/10.1016/j.apenergy.2015.07.055

[8] Romero Gómez, J., et al., Analysis and efficiency enhancement of a boil-off gas reliquefaction system with cascade cycle on board LNG carriers. Energy Conversion and Management, 2015. 94: p. 261-274. https://doi.org/10.1016/j.enconman.2015.01.074

[9] Mohd Noor, C.W., M.M. Noor, and R. Mamat, Biodiesel as alternative fuel for marine diesel engine applications: A review. Renewable and Sustainable Energy Reviews, 2018. 94: p. 127-142. https://doi.org/10.1016/j.rser.2018.05.031

[10] Chang, D., et al., A study on availability and safety of new propulsion systems for LNG carriers. Reliability Engineering \& System Safety, 2008. 93(12): p. 1877-1885. https://doi.org/10.1016/j.ress.2008.03.013.

[11] Kanbur, B.B., et al., Cold utilization systems of LNG: A review. Renewable and Sustainable Energy Reviews, 2017. 79: p. 1171-1188. https://doi.org/10.1016/j.rser.2017.05.161.

[12] Shin, Y. and Y.P. Lee, Design of a boil-off natural gas reliquefaction control system for LNG carriers. Applied Energy, 2009. 86(1): p. 37-44. https://doi.org/10.1016/j.apenergy.2008.03.019.

[13] Yu, Y.H., B.G. Kim, and D.G. Lee, Cryogenic reliability of the sandwich insulation board for LNG ship. Composite Structures, 2013. 95: p. 547-556. https://doi.org/10.1016/j.compstruct.2012.07.007.

[14] Fernández, I.A., et al., Review of propulsion systems on LNG carriers. Renewable and Sustainable Energy Reviews, 2017. 67: p. 1395-1411. https://doi.org/10.1016/j.rser.2016.09.095.

[15] Gohary, M.M.E. and I.S. Seddiek, Utilization of alternative marine fuels for gas turbine power plant onboard ships. International Journal of Naval Architecture and Ocean Engineering, 2013. 5(1): p. 2132. https://doi.org/10.2478/IJNAOE-2013-0115. 
[16] Thomson, H., J.J. Corbett, and J.J. Winebrake, Natural gas as a marine fuel. Energy Policy, 2015. 87: p. 153-167. https://doi.org/10.1016/j.enpol.2015.08.027.

[17] Ogden, J., et al., Natural gas as a bridge to hydrogen transportation fuel: Insights from the literature. Energy Policy, 2018. 115: p. 317-329. https://doi.org/10.1016/j.enpol.2017.12.049.

[18] Burel, F., R. Taccani, and N. Zuliani, Improving sustainability of maritime transport through utilization of Liquefied Natural Gas (LNG) for propulsion. Energy, 2013. 57: p. 412-420. https://doi.org/10.1016/j.energy.2013.05.002.

[19] Gilmore, R., et al., LNG carrier alternative propulsion systems. SNAME-Greek Sect; 2005.

[20] Vanem, E., et al., Analysing the risk of LNG carrier operations. Reliability Engineering \& System Safety, 2008. 93(9): p. 1328-1344. https://doi.org/10.1016/j.ress.2007.07.007.

[21] Komal, D. Chang, and S.-y. Lee, Fuzzy reliability analysis of dual-fuel steam turbine propulsion system in LNG carriers considering data uncertainty. Journal of Natural Gas Science and Engineering, 2015. 23: p. 148-164. https://doi.org/10.1016/j.jngse.2015.01.030.

[22] Bai, Y. and W.-L. Jin, Chapter 4 - LNG Carrier, in Marine Structural Design (Second Edition), Y. Bai and W.-L. Jin, Editors. 2016, Butterworth-Heinemann: Oxford. p. 49-71. https://doi.org/10.1016/B9780-08-099997-5.00004-6.

[23] Jung, D., S. Park, and K. Min, Selection of appropriate working fluids for Rankine cycles used for recovery of heat from exhaust gases of ICE in heavy-duty series hybrid electric vehicles. Applied Thermal Engineering, 2015. 81: p. 338-345. https://doi.org/10.1016/j.applthermaleng.2015.02.002.

[24] Mrzljak, V., I. Poljak, and T. Mrakovčić, Energy and exergy analysis of the turbo-generators and steam turbine for the main feed water pump drive on LNG carrier. Energy Conversion and Management, 2017. 140: p. 307-323. https://doi.org/10.1016/j.enconman.2017.03.007.

[25] Koroglu, T. and O.S. Sogut, Conventional and advanced exergy analyses of a marine steam power plant. Energy, 2018. 163: p. 392-403. https://doi.org/10.1016/j.energy.2018.08.119.

[26] Ekanem Attah, E. and R. Bucknall, An analysis of the energy efficiency of LNG ships powering options using the EEDI. Ocean Engineering, 2015. 110: p. 62-74. https://doi.org/10.1016/j.oceaneng.2015.09.040.

[27] Shin, Y. and Y.P. Lee, Design of a boil-off natural gas reliquefaction control system for LNG carriers. Applied Energy, 2009. 86(1): p. 37-44. https://doi.org/10.1016/j.apenergy.2008.03.019

[28] Raj, R., et al., A techno-economic study of shipping LNG to the Asia-Pacific from Western Canada by LNG carrier. Journal of Natural Gas Science and Engineering, 2016. 34: p. 979-992. https://doi.org/10.1016/j.jngse.2016.07.024.

[29] Mrzljak, V., I. Poljak, and V. Medica-Viola, Dual fuel consumption and efficiency of marine steam generators for the propulsion of LNG carrier. Applied Thermal Engineering, 2017. 119: p. 331-346. https://doi.org/10.1016/j.applthermaleng.2017.03.078.

[30] Moon, K., et al., Fire risk assessment of gas turbine propulsion system for LNG carriers. Journal of Loss Prevention in the Process Industries, 2009. 22(6): p. 908-914. https://doi.org/10.1016/i.jlp.2008.11.008.

[31] Gierusz, W., Simulation model of the LNG carrier with podded propulsion Part 1: Forces generated by pods. Ocean Engineering, 2015. 108: p. 105-114. https://doi.org/10.1016/j.oceaneng.2015.07.031.

[32] Bittante, A., F. Pettersson, and H. Saxén, Optimization of a small-scale LNG supply chain. Energy, 2018. 148: p. 79-89. https://doi.org/10.1016/j.energy.2018.01.120.

[33] Haglind, F., A review on the use of gas and steam turbine combined cycles as prime movers for large ships. Part III: Fuels and emissions. Energy Conversion and Management, 2008. 49(12): p. 3476-3482. https://doi.org/10.1016/j.enconman.2008.08.003.

[34] Tan, H., et al., A new boil-off gas re-liquefaction system for LNG carriers based on dual mixed refrigerant cycle. Cryogenics, 2018. 92: p. 84-92. https://doi.org/10.1016/j.cryogenics.2018.04.009.

[35] MAN. Propulsion Trends in LNG Carriers: Two-stroke Engines. 201315 October 2018)]; Available from: https:/Www.mandieselturbo.com/docs/default-source/shopwaredocuments/propulsion-trends-inlngb395958927f2417aa98957b04cbb684a.pdf?sfvrsn=4.

[36] Bowie, S. Top 10 largest exporters of liquid natural gas. 201817 October 2018)]; Available from: https://www.energydigital.com/top10/top-10-largest-exporters-liquid-natural-gas.

[37] EIA. China becomes world's second largest LNG importer, behind Japan, U.S. Energy Information Administration. $2018 \quad 17$ October 2018]; Available from: https://www.eia.gov/todayinenergy/detail.php?id=35072.

[38] SEA-DISTANCES.ORG. Sea Distances/port distances - online tool for calculation distances between sea ports. 201817 October 2018)]; Available from: https://sea-distances.org/.

[39] Farooqui, Z.M., K. John, and N. Sule, Evaluation of anthropogenic air emissions from marine engines in a coastal urban airshed of Texas. Journal of Environmental Protection, 2013. 4: p. 722-731. https://doi.org/10.4236/jep.2013.47083. 
[40] Ammar, N.R. and I.S. Seddiek, Eco-environmental analysis of ship emission control methods: Case study RO-RO cargo vessel. Ocean Engineering, 2017. 137: p. 166 - 173. https://doi.org/10.1016/j.oceaneng.2017.03.052.

[41] Department of Energy \& Climate Change. CHP - Environmental, a detailed guide for CHP developersPart 3. $2008 \quad 27$ October 2018)]; Available from: https://assets.publishing.service.gov.uk/government/uploads/system/uploads/attachment_data/file/3451 73/Part_3_CHP_Environmental.pdf.

[42] ICF. Towboat emission reduction feasibility study. 2009.

[43] ICF. Current methodologies in preparing mobile source port-related emission inventories. 2009; 50-60.

[44] Banawan, A.A., M.M. El Gohary, and I.S. Sadek, Environmental and economical benefits of changing from marine diesel oil to natural-gas fuel for short-voyage high-power passenger ships. Proceedings of the Institution of Mechanical Engineers Part M-Journal of Engineering for the Maritime Environment, 2010. 224(M2): p. 103-113. https://doi.org/10.1243/14750902JEME181.

[45] Seddiek, I.S. and M.M. Elgohary, Eco-friendly selection of ship emissions reduction strategies with emphasis on $\mathrm{SO}_{x}$ and $\mathrm{NO}_{x}$ emissions. International Journal of Naval Architecture and Ocean Engineering, 2014. 6(3): p. 737-748. https://doi.org/10.2478/Ijnaoe-2013-0209.

[46] IMO. Report of the marine environment protection committee on its sixty-second session 201127 October 2018)]; Available from: http://www.crs.hr/Portals/0/MEPC\%2062-24.pdf.

[47] Ahn, J., et al., Strategy for selecting an optimal propulsion system of a liquefied hydrogen tanker. International Journal of Hydrogen Energy, 2017. 42(8): p. 5366-5380. https://doi.org/10.1016/j.ijhydene.2017.01.037.

[48] Głomski, P. and R. Michalski, Problems with Determination of Evaporation Rate and Properties of Boil-off Gas on Board LNG Carriers. Journal of Polish CIMAC, 2011. 6(1): p. 133-140.

[49] Zakaria, M., K. Osman, and M. Musa, Boil-Off Gas Formation inside Large Scale Liquefied Natural Gas (LNG) Tank Based on Specific Parameters. Applied Mechanics and Materials, 2012. 229: p. 690694. https://doi.org/10.4028/www.scientific.net/AMM.229-231.690.

[50] Dobrota, D., B. Lalić, and I. Komar, Problem of Boil-off in LNG Supply Chain. Transaction on maritime science, 2013. 2: p. 91-100. https://doi.org/10.7225/toms.v02.n02.001

[51] Welaya, Y.M.A., M.M. El Gohary, and N.R. Ammar, A comparison between fuel cells and other alternatives for marine electric power generation. International Journal of Naval Architecture and Ocean Engineering, 2011. 3(2): p. 141-149. https://doi.org/10.3744/Jnaoe.2011.3.2.141.

[52] $\mathrm{Li}, \mathrm{J} ., \mathrm{B} . \mathrm{Wu}$, and $\mathrm{G}$. Mao, Research on the performance and emission characteristics of the LNG-diesel marine engine. Journal of Natural Gas Science and Engineering, 2015. 27: p. 945-954. https://doi.org/10.1016/j.jngse.2015.09.036.

[53] Talluri, L., D.K. Nalianda, and E. Giuliani, Techno economic and environmental assessment of Flettner rotors for marine propulsion. Ocean Engineering, 2018. 154: p. 1-15. https://doi.org/10.1016/j.oceaneng.2018.02.020.

[54] Seddiek, I.S., M.M. Elgohary, and N.R. Ammar, The hydrogen-fuelled internal combustion engines for marine applications with a case study. Brodogradnja, 2015. 66(1): p. 23-38.

[55] Ammar, N.R. and N.F.S.H. Alshammari, Overview of the Green Hydrogen Applications in Marine Power Plants Onboard Ships. International Journal of Multidisciplinary and Current Research (IJMCR), 2018. 6: p. 84-89. https://doi.org/10.14741/ijmcr.v6i01.10912

[56] Ammar, N.R. and I.S. Seddiek, Thermodynamic, environmental and economic analysis of absorption air conditioning unit for emissions reduction onboard passenger ships. Transportation Research Part D: Transport and Environment, 2018. 62: p. 726-738. https://doi.org/10.1016/j.trd.2018.05.003.

[57] IMO, Third IMO Greenhouse Gas Study 2014 : Safe, secure and efficient shipping on clean oceans, 2015: London: International Maritime Organization (IMO).

[58] Devanney, J., The impact of the energy efficiency design index on very large crude carrier design and $\mathrm{CO}_{2}$ emissions. Ships and Offshore Structures, 2011. 6(4): p. 355-368. https://doi.org/10.1080/17445302.2010.546651.

[59] GL. Guidelines for Determination of the Energy Efficiency Design Index. 20133 December 2017)]; Available from: http://rules.dnvgl.com/docs/pdf/gl/maritimerules2016July/gl_vi-13-1_e.pdf.

[60] IRCLASS. Ship Energy Efficiency Management Plan (SEEMP), guidance notes for ship owners and ship operators. 20136 December 2017)]; Available from: http://www.irclass.org/media/1397/shipenergy-efficiency-management-plan.pdf.

[61] Agnolucci, P., T. Smith, and N. Rehmatulla, Energy efficiency and time charter rates: Energy efficiency savings recovered by ship owners in the Panamax market. Transportation Research Part A: Policy and Practice, 2014. 66(Supplement C): p. 173-184. https://doi.org/10.1016/j.tra.2014.05.004. 
[62] Ammar, N.R., Energy- and cost-efficiency analysis of greenhouse gas emission reduction using slow steaming of ships: case study RO-RO cargo vessel. Ships and Offshore Structures, 2018. 13(8): p. 868876. https://doi.org/10.1080/17445302.2018.1470920.

[63] IMO, Resolution MEPC.213(63), 2012 Guidelines for the development of a ship energy efficiency management plan (SEEMP), 2012.

[64] IMO, Resolution MEPC 245(66): 2014 guidelines on the method of calculation of the attained Energy Efficiency Design Index (EEDI) for new ships. MEPC 66/21/Add.1, Annex 5, 4 April 2014. 2014, International Maritime Organization: London.

[65] Hunt, E. and B. Butman. Marine engineering economics and cost analysis. 1995.

[66] Jeong, J., et al., Comparative analysis of a hybrid propulsion using LNG-LH2 complying with regulations on emissions. International Journal of Hydrogen Energy, 2018. 43(7): p. 3809-3821. https://doi.org/10.1016/j.ijhydene.2018.01.041.

[67] GE. LM2500, Gas Turbine for LNG Fueled Propulsion. 2013; Available from: https://www.ge.com/content/dam/gepower-pgdp/global/en_US/documents/product/lm2500-lngproduct-sheet.pdf.

[68] Mitsubishi. Steam Turbine Generators (AT-Type). 201710 October 2018]]; Available from: https://www.mhi-mme.com/products/boilerturbine/steam_turbine.html.

[69] MAN. Marine Engines \& Systems. 201810 October 2018]]; Available from: https://marine.manes.com/.

[70] Bortnowska, M., Development of new technologies for shipping natural gas by sea. Polish Maritime Research, 2009. 16(3): p. 70-78. https://doi.org/10.2478/v10012-008-0036-2.

[71] Pauschert, D. Study of equipment prices in the power sector. ESMAP Technical Paper 122/09. Washington, DC: Energy Sector Management Assistance Program. 200910 October 2018]]; Available from: 09_GBL_Study_of_Equipment_Prices_in_the_Power_Sector.pdf.

[72] International Gas Union. World LNG report-2015 edition. 201510 October 2018)]; Available from: http://www.igu.org/sites/default/files/node-page-field_file/IGU-World\%20LNG\%20Report2015\%20Edition.pdf.

[73] Bunkerworld. Bunkerworld. Fuel prices. Octobern2018 15 October 2018)]; Available from: http://www.bunkerworld.com/prices/.

[74] Knoema. Natural gas prices forcast: long term 2018 to 2030 data and charts. 201815 October 2018)]; Available from: https://knoema.com/ncszerf/natural-gas-prices-forecast-long-term-2018-to-2030-dataand-charts.

[75] Trading Economics. Natural gas 1990-2018 201815 October 2018)]; Available from: https://tradingeconomics.com/commodity/natural-gas.

[76] Mikelis, N.E., A statistical overview of ship recycling. J. Marit. Affairs, 2008. 7(1): p. $227-239$. https://doi.org/10.1007/BF03195133

Submitted: $\quad$ 26.11.2018. $\quad$ Nader R. Ammar ${ }^{1,2}$, Nader@alexu.edu.eg (corresponding author)

Accepted: $\quad$ 11.06.2019. $\quad{ }^{1}$ Department of Marine Engineering, Faculty of Maritime Studies, King Abdulaziz University, 21589 Jeddah, Saudi Arabia.

${ }^{2}$ Department of Naval Architecture and Marine Engineering, Faculty of Engineering, Alexandria University 21544 Alexandria, Egypt 